Pacific Journal of Mathematics

CORRECTION TO: "SYMPLECTIC BORDISM,
STIEFEL-WHITNEY NUMBERS, AND A NOVIKO

DON DAVID PORTER 
Correction to

\section{SYMPLECTIC BORDISM, STIEFEL-WHITNEY NUMBERS AND A NOVIKOV RESOLUTION}

DoN PORTER

\section{Volume 35 (1970), 205-212}

Larry Smith has pointed out that Proposition 7, p. 210 is wrong. Consequently my proof of Theorem A is incorrect, although Theorem $A$ itself is true (Floyd, Stiefel-Whitney numbers of quaternionic and related manifolds, Trans. Amer. Math. Soc., 155 (1971), 77-94, and Segal, Divisibility conditions on characteristic numbers of stably symplectic manifolds, Proc. Amer. Math. Soc., 27 (1971), 411-415).

Correction to

\section{ALMOST SMOOTH PERTURBATIONS OF SELF-ADJOINT OPERATORS}

J. B. ButLeR

\section{Volume 35 (1970), 297-306}

(1) In condition (a) on p. 304 add the statement:

$$
\text { " } f_{1} \text { even, } f_{2} \text { odd, }\left|f_{1}\right|=\left|f_{2}\right| "
$$

(2) Change the inequality at the bottom of p. 304 to the following:

$$
\int_{-\infty}^{\infty} f_{1}^{2} d x\left(\int_{0}^{\infty}\left|f_{n+1}\right| d x\right)^{2}<(128)^{-1 "}
$$

(3) Replace the last two sentences at the bottom of p. 305 with the following:

"In this case we assume that $A, B$ are real operators, $A u=$ $f_{2}(x)\left(h_{2}, u\right), B u=f_{1}(x) u$, where $f_{1}, f_{2}, f_{3}, g_{2}, g_{3}$ are in $C(0, \infty) \cap L_{1}(0, \infty) \cap$ $L_{2}(0, \infty),\left\|h_{2}\right\|=1$, and

$$
\int_{0}^{\infty} f_{1}^{2} d x\left(\int_{0}^{\infty}\left|f_{3}\right| d x\right)^{2}<(256)^{-1}
$$

so that the perturbation is degenerate. Again $L^{1}=L^{0}+B A$ is almost smooth but not smooth with respect to $L^{0}[3$, p. 381]." 


\section{PACIFIC JOURNAL OF MATHEMATICS}

\section{EDITORS}

\author{
H. SAMELSON \\ Stanford University \\ Stanford, California 94305 \\ C. R. HOBBY \\ University of Washington \\ Seattle, Washington 98105
}

\section{J. DugundjI}

Department of Mathematics University of Southern California Los Angeles, California 90007

\section{RICHARD ARENS}

University of California

Los Angeles, California 90024

\section{ASSOCIATE EDITORS}
E. F. BECKENBACH
B. H. NeumanN
F. WOLF
K. YosHIDA

\section{SUPPORTING INSTITUTIONS}

\author{
UNIVERSITY OF BRITISH COLUMBIA \\ CALIFORNIA INSTITUTE OF TECHNOLOGY \\ UNIVERSITY OF CALIFORNIA \\ MONTANA STATE UNIVERSITY \\ UNIVERSITY OF NEVADA \\ NEW MEXICO STATE UNIVERSITY \\ OREGON STATE UNIVERSITY \\ UNIVERSITY OF OREGON \\ OSAKA UNIVERSITY
}

\author{
UNIVERSITY OF SOUTHERN CALIFORNIA \\ STANFORD UNIVERSITY \\ UNIVERSITY OF TOKYO \\ UNIVERSITY OF UTAH \\ WASHINGTON STATE UNIVERSITY \\ UNIVERSITY OF WASHINGTON \\ ${ }^{*} \stackrel{*}{*}{ }^{*}$
AMERICAN MATHEMATICAL SOCIETY
NAVAL WEAPONS CENTER
}

The Supporting Institutions listed above contribute to the cost of publication of this Journal, but they are not owners or publishers and have no responsibility for its content or policies.

Mathematical papers intended for publication in the Pacific Journal of Mathematics should be in typed form or offset-reproduced, (not dittoed), double spaced with large margins. Underline Greek letters in red, German in green, and script in blue. The first paragraph or two must be capable of being used separately as a synopsis of the entire paper. The editorial "we" must not be used in the synopsis, and items of the bibliography should not be cited there unless absolutely necessary, in which case they must be identified by author and Journal, rather than by item number. Manuscripts, in duplicate if possible, may be sent to any one of the four editors. Please classify according to the scheme of Math. Rev. Index to Vol. 39. All other communications to the editors should be addressed to the managing editor, Richard Arens, University of California, Los Angeles, California, 90024.

50 reprints are provided free for each article; additional copies may be obtained at cost in multiples of 50 .

The Pacific Journal of Mathematics is published monthly. Effective with Volume 16 the price per volume (3 numbers) is $\$ 8.00$; single issues, $\$ 3.00$. Special price for current issues to individual faculty members of supporting institutions and to individual members of the American Mathematical Society: $\$ 4.00$ per volume; single issues $\$ 1.50$. Back numbers are available.

Subscriptions, orders for back numbers, and changes of address should be sent to Pacific Journal of Mathematics, 103 Highland Boulevard, Berke'ey, California, 94708.

PUBLISHED BY PACIFIC JOURNAL OF MATHEMATICS, A NON-PROFIT CORPORATION

Printed at Kokusai Bunken Insatsusha (International Academic Printing Co., Ltd.), 270, 3-chome Totsuka-cho, Shinjuku-ku, Tokyo 160, Japan. 


\section{Pacific Journal of Mathematics}

\section{Vol. 43, No. $3 \quad$ May, 1972}

Max K. Agoston, An obstruction to finding a fixed point free map on a manifold.... 543

Nadim A. Assad and William A. Kirk, Fixed point theorems for set-valued mappings

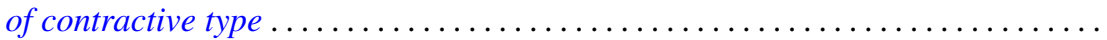

John Winston Bunce, Characterizations of amenable and strongly amenable

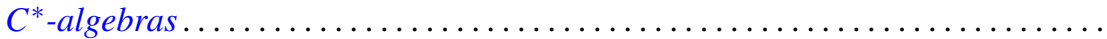

Erik Maurice Ellentuck and Alfred Berry Manaster, The decidability of a class of

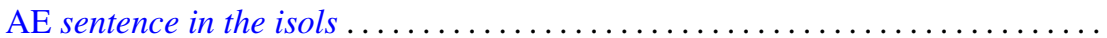

U. Haussmann, The inversion theorem and Plancherel's theorem in a Banach

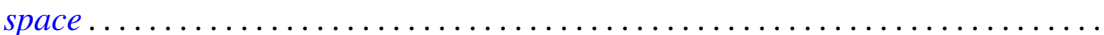

Peter Lawrence Falb and U. Haussmann, Bochner's theorem in infinite dimensions.

Peter Fletcher and William Lindgren, Quasi-uniformities with a transitive base ..... Dennis Garbanati and Robert Charles Thompson, Classes of unimodular abelian

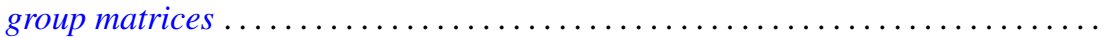

Kenneth Hardy and R. Grant Woods, On c-realcompact spaces and locally bounded normal functions

Manfred Knebusch, Alex I. Rosenberg and Roger P. Ware, Grothendieck and Witt rings of hermitian forms over Dedekind rings .......................

George M. Lewis, Cut loci of points at infinity.

Jerome Irving Malitz and William Nelson Reinhardt, A complete countable $L_{\omega_{1}}^{Q}$ theory with maximal models of many cardinalities . . . . . . . . . . . . . . . . .

Wilfred Dennis Pepe and William P. Ziemer, Slices, multiplicity, and Lebesgue

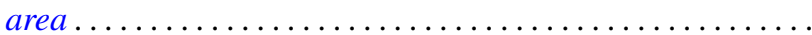

Keith Pierce, Amalgamating abelian ordered groups . .

Stephen James Pride, Residual properties of free groups . . . . . . . . . . . . . 725

Roy Martin Rakestraw, The convex cone of n-monotone functions .

T. Schwartzbauer, Entropy and approximation of measure preserving transformations .

Peter F. Stebe, Invariant functions of an iterative process for maximization of a polynomial...

Kondagunta Sundaresan and Wojbor Woyczynski, L-orthogonally scattered

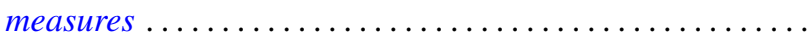

Kyle David Wallace, $C_{\lambda}$-groups and $\lambda$-basic subgroups $\ldots \ldots \ldots$

Barnet Mordecai Weinstock, Approximation by holomorphic functions on certain

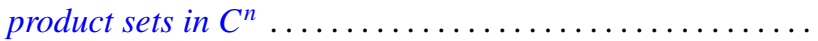

Donald Steven Passman, Corrections to: "Isomorphic groups and group rings”.

Don David Porter, Correction to: "Symplectic bordism, Stiefel-Whitney numbers, and a Novikov resolution"

John Ben Butler, Jr., Correction to: “Almost smooth perturbations of self-adjoint operators".

Constantine G. Lascarides, Correction to: "A study of certain sequence spaces of Maddox and a generalization of a theorem of Iyer" ...... ...

George A. Elliott, Correction to: "An extension of some results of takesaki in the reduction theory of von neumann algebras" ......................... 